\title{
ESSAY
}

\section{0 years: from IVF to stem cells}

\section{Ruth Deech, former chair of Britain's Human Fertilisation and Embryology Authority, reflects on how the science that gave an infertile couple a baby has been extended to saving lives.}

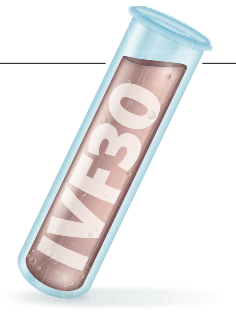

W / hen Louise Brown was born of the first successful in vitro fertilization (IVF) in 1978, the reaction was intense and mixed. Some 5,000 couples immediately signed up for the same treatment, while the Catholic Church promptly objected, drawing battle lines that are still evident today. Reporters besieged the hospital in which the birth took place. A bomb scare, perhaps called in by reporters hoping to get a glimpse of the mother, Lesley Brown, cleared the maternity building. More IVF births followed quickly, in Australia in 1980 and the United States in 1981, and a feeling arose among everyone involved that action should be taken to ensure future advances in reproductive technology would be controlled and monitored.

The British response to this has proved a massive success. By creating a climate in which embryo research is regulated and supported, Britain encouraged the use of that research to save lives.

It began in the 1980s with a move typical of how the British government handles complex issues: the establishment of a committee of the 'great and the good' charged with considering the future. The committee's 1984 report was the foundation of the full-scale legislation put in place in 1990: the Human Fertilisation and Embryology Act. This brought into being the now-famous regulatory authority the Human Fertilisation and Embryology Authority (HFEA) - a body of around 20 people, half scientists and half lay-people. The act itself could be interpreted broadly, so the HFEA had the flexibility and authority to make decisions on a case-by-case basis as reproductive medicine advanced. As I discovered while chairing the HFEA from 1994 to 2002 - one of the greatest privileges of my career - it is salutary for an ethics body to have to make immediate decisions involving real individuals and their health.

Britain is now admired internationally for its policies and practice in reproductive biology. Perhaps its main distinction is in having created a set of nationally uniform and

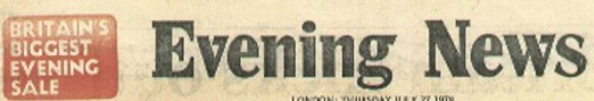

Meet Louise, the world's first test-tube arrival SUPFRBABE

Wide-eyed Louise Brown pictured in hospital 18 hours after she was born. Today she's doing well. See Page Three enforceable guidelines that are applicable to both research and assisted-reproduction practice. In the United States, assisted reproduction is nearly an unregulated black market, guided by toothless 'rules' from non-regulatory bodies - fertility clinics can offer sex selection at their own discretion, for example. Meanwhile, US researchers are hampered by strict laws, including the inability to use federal funds to create new embryonic stem-cell lines. The reports from the US national council on bioethics are no substitute for a regulatory body such as the HFEA, which combines reflection with statutory powers of inspection and enforcement.

\section{Legal sanction}

The 30-year anniversary of IVF comes at the same time as a fresh bill in Britain, expected to be passed into law later this year. The bill gives legal sanction to mixed animal-human embryos, preimplantation genetic diagnosis and saviour siblings, while banning most cases of sex selection. In practice this will change little, but it is a welcome statement that the British public and lawmakers recognize the tremendous advances made in alleviating infertility and disease by our clinicians and embryologists, and that progress in this field will remain as controlled and thoughtful as it has been in the past. It is an achievement of which Britain should be proud.

Things have not been easy for the HFEA along the way. It has faced many fights with the law and the popular press; it has struggled to keep clinicians in line, avoid commercialism, safeguard the health of donors and patients, and above all explain to the public at large the issues involved.

Ethical quandaries were raised by the science of embryo diagnosis, for example, which developed in tandem with IVF. Preimplantation genetic diagnosis meant that a couple aware of a genetic disease within the family could choose an embryo found to be clear of the threatened disease. The technique also made possible the selection of an embryo that would, if it became a baby, provide a sick older sibling with matching tissue that might save his or her life.

This was tested first in the United States with the case of Molly Nash, who was born in 1994 with Fanconi's anaemia. The only cure seemed to be a transfusion of bone marrow but no matching donor could be found. After a long struggle, against both bureaucracy and biology, in 2000 her parents eventually conceived another baby through IVF, selected to be free of anaemia and a good tissue match for Molly.

This expensive and rarely successful procedure continues in the United States without regulation, despite concerns that it involves the disposal of dozens of 'unsuitable' embryos and opens the door to selection for other traits, from athletic ability to blue eyes. In Britain, those same concerns were raised, but with a regulatory body to oversee each decision. In 2002, the HFEA gave permission for a saviour 
sibling in the case of the Hashmi family, whose son had $\beta$-thalassaemia (sadly, their efforts to find a disease-free matching embryo met with failure). The legality of testing for saviour siblings was challenged by pro-life groups in the British courts from 2003 to 2005. But in this case as in others, the court took a decision that favoured the extension of science; it agreed that the HFEA should be free to use its discretion in allowing those advances.

The promotion of research was also the driving force behind the HFEA's decisions on animal-hybrid embryos. The HFEA has allowed (and soon British law will rubber-stamp) the insertion of human DNA into an animal egg, to address the shortage of human eggs for research. Surprisingly, this gave rise to the most public concern in the 2008 bill discussions, although most scientists saw no ethical difficulty with creating hybrid embryos that would be allowed to develop for no longer than 14 days.

\section{Enter the clones}

Perhaps the greatest success of the HFEA came after the cloning of Dolly the sheep in 1996 - another British 'first'. The word 'cloning' aroused considerable public concern, as the public imagined identical humans being pumped out of test tubes: an attitude engendered by films and novels. Britain aimed to embrace therapeutic oppor-

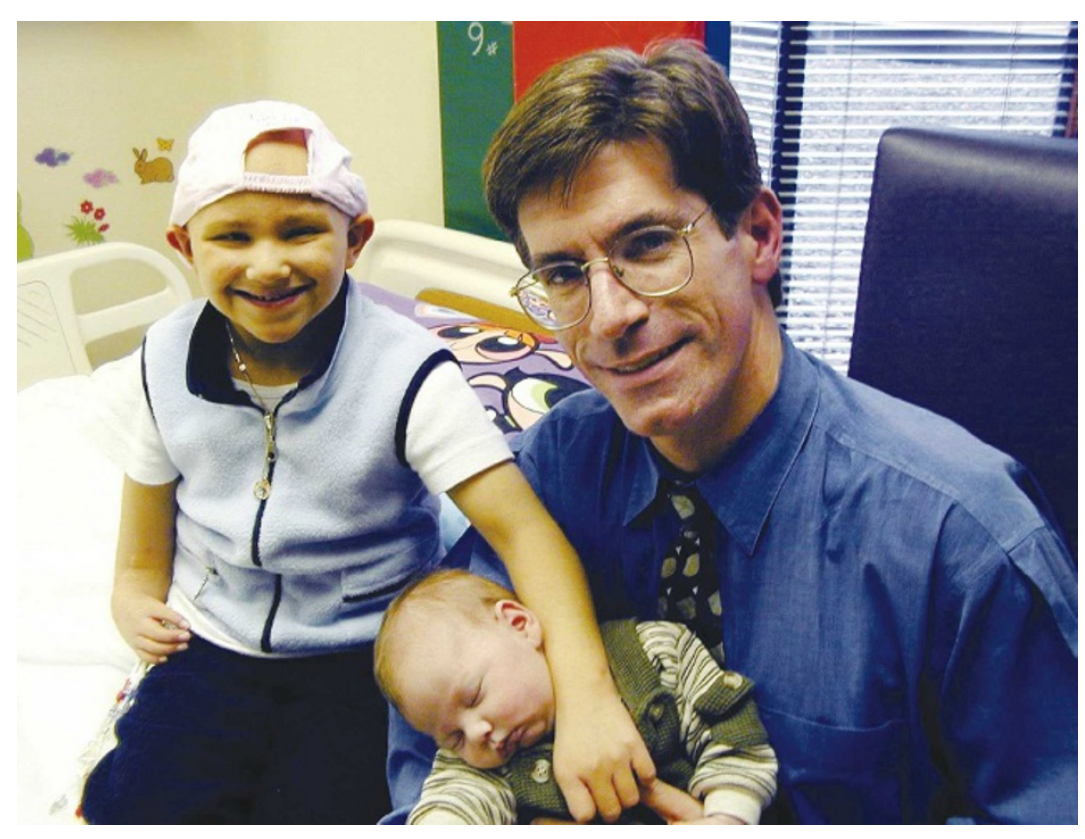

Molly Nash (left) received healthy tissue from her IVF baby brother Adam. excessive treatment in Israel, which allows women almost unlimited attempts at IVF, and has the highest per-capita rate of the technique's usage. China has started to implement permissive national guidelines; the Chinese attitude towards the embryo is not burdened with Christian views. gists following the ongoing health of these children and the success of IVF techniques.

Australia also started to regulate reproductive technologies early, and has likewise been able to respond nimbly to changing situations. Some other countries have joined the legislative bandwagon a little late, largely emulating the current British system; Canada is one example.

\section{A long road ahead}

Some US states, including California, are pushing ahead with locally regulated stem-cell work. The California Institute for Regenerative Medicine in San Francisco has an Independent Citizens' Oversight Committee, echoing the British approach. The United States as a whole, however, has a mountain to climb if the next administration approves federal funding for stemcell research. It has no nationwide prohibitions on keeping embryos for more than 14 days, no databases of donors and treatments, no uniform safety standards and no control on the sale and advertising of gametes. Stem-cell research can hardly be monitored in a vacuum. I predict that there will be a rush to basic registration and monitoring once the current federal ban is lifted. It will be hard to form rules that might encumber what is now a big business in assisted reproduction; rules that would differ from state to state and that will probably tunities arising from this success, and to rescue the word 'cloning' from the general disapprobation of 'reproductive cloning.

After a thorough investigation of the issues by the many interested British medical and ethical organizations (including the HFEA), parliament was persuaded in 2001 to broaden the law and permit 'cell nuclear replacement' for investigating serious disease. As a result, embryo work moved from being directed solely towards infertility to searching for cures from embryo-derived stem cells. Thus the saving of life was added to the other ethical principles applicable to embryology: the safety and welfare of the child and mother, the autonomy of those involved and respect for the embryo. Britain became a safe and desirable location for stem-cell research.

In retrospect it was a clear advantage for Britain to have enacted legislation at the outset, before anyone knew what complexities lay

In many other countries, a lack of early controls gave disagreements over controversial issues a chance to become entrenched, making it harder to formulate research-permissive — or even any — regulatory legislation. Italy, for example, went from being totally unregulated to having prohibitions based on the firm religious beliefs of the majority of the population: in 2004, embryo freezing and research were banned and IVF was restricted to heterosexual couples.

Some evidence suggests that more comprehensive national regulation, established early, accords with swift and confident technological advances. But this doesn't always hold true; the international responses have been wide-ranging. Israel and Belgium have very advanced embryology research but disjointed laws on fertility treatments. These laws are so liberal that there has been some disquiet about reproductive tourism to Belgium and attract constitutional challenges as infringing on the liberty of citizens and physicians.

Extensive legal regulation has drawbacks: expense, bureaucracy and a struggle for domination between politicians, churchmen, scientists, clinicians and the public. Yet I feel that its existence in Britain put this small country at the forefront of research and gave it an authoritative voice in international discussions on embryology. Regulation has enabled progress to be made in tandem with public acceptance and in a safe zone for clinicians and scientists who follow the rules. The passage of the 2008 bill will clear the path for scientific advances of the future: both foreseen and unforeseen.

Ruth Deech is an independent member of the House of Lords and co-author of From IVF to Immortality: Controversy in the Era of Reproductive Technology.

See Editorial, page 253, and News, page 260. 